\title{
Model Predictive Control Using Adaline
}

\author{
SAMEK, D. \& DOSTAL, P.
}

Abstract: This paper deals with nonlinear model predictive control using artificial neural networks. After short introduction to the model predictive control approach this contribution presents an application of adaptive linear neural network for predictive control of nonlinear system. This paper shows ability of adaptive linear network to predict nonlinear system output and to be used for predictive control of these systems. Multilayer feed-forward neural networks are used as a comparative method.

Key words: model predictive control, artificial neural networks, ADALINE
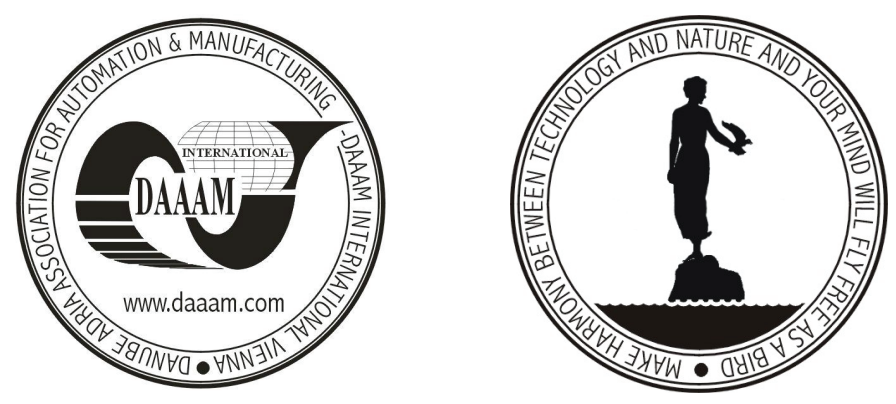

Authors' data: Ing. Ph.D. Samek D.[avid]*, Prof. Ing. CSc. Dostal P.[etr]**, *Faculty of Technology, Tomas Bata University in Zlin, **Faculty of Applied Informatics, Tomas Bata University in Zlin, Czech Republic, samek@ft.utb.cz, dostalp@fai.utb.cz

This Publication has to be referred as: Samek, D. \& Dostal, P. (2006). Model Predictive Control Using Adaline, Chapter 43 in DAAAM International Scientific Book 2006, B. Katalinic (Ed.), Published by DAAAM International, ISBN 3-90150947-X, ISSN 1726-9687, Vienna, Austria

DOI: $10.2507 /$ daaam.scibook.2006.43 